\title{
KAEDAH PENYELESAIAN PERTIKAIAN DI TRIBUNAL TUNTUTAN PENGGUNA MALAYSIA: SATU KAJIAN LAPANGAN
}

\section{(Dispute Settlement Method at the Tribunal for Consumer Claims Malaysia: A Field Research)}

\author{
Nadiatul Husna Mohd Amin \\ husnamohdamin@gmail.com
}

\author{
Zalina Zakaria* \\ zalina_jsu@um.edu.my \\ Mohd Zaidi Daud \\ mzaidi@um.edu.my \\ Jabatan Syariah dan Undang-Undang, \\ Akademi Pengajian Islam, Universiti Malaya.
}

Terbit dalam talian (published online): 7 Januari 2021

Sila rujuk: Nadiatul Husna Mohd Amin, Zalina Zakaria dan Mohd Zaidi Daud. Kaedah Penyelesaian di Tribunal Tuntutan Pengguna Malaysia: Satu Kajian Lapangan. Kanun: Jurnal Undang-undang Malaysia, 33(1), 159-184.

\begin{abstract}
Abstrak
Pelbagai perundangan pengguna telah dikuatkuasakan oleh kerajaan bertujuan untuk memberikan perlindungan terbaik kepada pengguna di Malaysia. Perundangan pengguna tersebut termasuklah penubuhan Tribunal Tuntutan Pengguna Malaysia (TTPM) yang diwujudkan di bawah Akta Perlindungan Pengguna 1999. Tujuan penubuhannya adalah untuk memberikan perlindungan sebaik mungkin kepada pengguna akan hak mereka. Namun begitu, terdapat beberapa isu yang timbul berkenaan dengan TTPM, antaranya termasuklah isu bidang kuasa TTPM yang terhad serta ketidakfahaman pengguna tentang peranan dan fungsi bahawa TTPM sebagai medium tebus rugi bagi mereka. Bagi
\end{abstract}


memenuhi objektif ini, kajian ini menggunakan kaedah metodologi kualitatif bagi mengumpulkan maklumat dengan cara temu bual dan pemerhatian yang dijalankan di TTPM. Kajian ini mendapati bahawa TTPM telah memainkan peranan yang penting dalam penyediaan landasan bagi tuntutan pengguna. Kewujudan TTPM sebagai medium perlindungan pengguna di Malaysia perlu dimanfaatkan sebaikbaiknya oleh pengguna. Sungguhpun begitu, peranan dan fungsi TTPM perlu dipertingkatkan kepada tahap yang lebih baik. Artikel ini juga mengemukakan beberapa cadangan yang boleh dipertimbangkan oleh pihak berkaitan untuk meningkatkan perlindungan pengguna di negara ini, dan TTPM khususnya.

Kata kunci: Tribunal Tuntutan Pengguna Malaysia, tuntutan, remedi

\begin{abstract}
The Malaysian government has enforced numerous consumer protection policies as a measure to provide consumers with the best consumer protection. This includes the establishment of the Tribunal for Consumer Claims Malaysia (TTPM), which was established under the Consumer Protection Act 1999. The aim was to ensure consumers receive the best protection of their rights. However, numerous issues have been highlighted, such as the TTPM's limited jurisdiction followed by inadequate understanding of consumers concerning the role and function of TTPM as a platform for remedial claims. Aiming to address the objectives of this research, the current study employed a qualitative approach to gather information by way of interview and observation. This study finds that the TTPM plays a very important role in providing a platform for remedial claims for consumers in Malaysia. The existence of the TTPM as a medium for consumer protection should be well-exploited as it benefits consumers. However, the roles and functions of the TTPM should be further developed. Thus, it is recommended that the relevant parties take steps to improve consumer protection rights in this country, in particular involving the TTPM.
\end{abstract}

Keywords: Tribunal for Consumer Claims Malaysia, claim, remedy 


\section{PENGENALAN}

Perkembangan isu kepenggunaan serta perkembangan sistem pasaran dalam pelbagai aspek termasuklah dalam urusan ekonomi dan perdagangan pada abad ke-20 kini, seiring dengan revolusi perubahan zaman yang semakin canggih, memberikan impak terhadap pasaran pengguna yang memerlukan perlindungan untuk pelbagai aspek khususnya dari sudut perundangan bagi memastikan hak pengguna terjamin (Sakina \& Rahmah, 2011: 1-2).

Pemimpin utama yang telah memberikan penekanan terhadap konsep perlindungan pengguna secara menyeluruh dan bertanggungjawab dalam mewujudkan Akta Perlindungan Pengguna 1999 yang pertama di Malaysia ialah Datuk Seri Megat Junid Megat Ayob yang memegang jawatan sebagai Menteri Perdagangan Dalam Negeri dan Hal Ehwal Pengguna pada tahun 1999. Beliau telah mengambil masa yang agak lama, iaitu selama sembilan tahun untuk menubuhkan akta tersebut bagi memperjuangkan dan melindungi hak pengguna di Malaysia dengan lebih baik (Mohd Hamdan, 2005: 25). Selain itu, pemimpin dunia pertama yang telah memberikan penekanan berkenaan konsep perlindungan pengguna ialah Presiden John F. Kennedy. Beliau telah mengiktiraf hak pengguna buat pertama kalinya melalui dewan perundangan negara melalui "Perisytiharan Hak Pengguna". Kennedy telah mengisytiharkan hak pengguna, ${ }^{1}$ iaitu hak mendapatkan keselamatan, hak mendapatkan informasi, hak mendapatkan pilihan dan hak mendapatkan pendengaran (Afida Mastura, 2001: 44). Setelah itu, Consumers International telah menambah empat hak pengguna daripada yang telah diutarakan oleh John F. Kennedy, iaitu hak mendapatkan keperluan asas, hak mendapatkan alam sekitar yang bersih dan selamat, hak mendapatkan ganti rugi atau pampasan dan hak mendapatkan pendidikan pengguna. Kesemua hak tersebut kini menjadi landasan bagi perjuangan pergerakan pengguna di seluruh dunia termasuklah Malaysia.

1 Petikan ucapan oleh John F. Kennedy: "Special Message to the Congress on Protecting the Consumer Interest.," semasa membentangkan usul perundangan pengguna kepada Kongres Amerika Syarikat pada 15 Mac 1962, dicapai 16 Mac 2019, http://www. presidency.ucsb.edu/ws/?pid=9108.

2 Consumers International dahulu dikenali sebagai International Organisation of Consumer Unions (IOCU) yang beroperasi sejak tahun 1960 merupakan sebuah badan yang terdiri dari lebih 200 pertubuhan pengguna dari seluruh dunia. Rujuk https://www. consumersinternational.org/ 
Oleh itu, pengguna perlu dibekalkan dengan pengetahuan tentang hak-hak mereka, kemahiran dan taktik tertentu untuk memainkan peranan mereka sebagai pengguna yang rasional dan bertanggungjawab. Hal ini penting supaya pengguna mendapat keadilan yang sewajarnya, dan mengelakkan daripada ditindas sekali gus membangkitkan liabiliti sivil terhadap peniaga yang tidak bertanggungjawab (Afida Mastura, 2001: 2).

Sebagai pengguna, hak untuk mendapatkan penghakiman yang adil termasuklah dari segi tebus rugi atas kerugian yang dialami berbangkit daripada penipuan. Misalnya pembelian barangan dan perkhidmatan yang tidak adil yang berbentuk memperdaya dan mengelirukan, barangan yang tidak berkualiti dan sebagainya sangat diberikan perhatian oleh pihak berwajib yang memainkan peranan utama dalam menjaga kepentingan pengguna (Joon, \& Sakina, 2016: 72-74). Lanjutan daripada itu, di Malaysia, sebuah badan bebas, iaitu Tribunal Tuntutan Pengguna Malaysia (TTPM) telah ditubuhkan dan diberikan mandat untuk menjalankan kuasa dan peranannya. Batasan perundangan telah ditetapkan di bawah Seksyen 85, Bahagian XII Akta Perlindungan Pengguna 1999 [Akta 599], yang berkuat kuasa pada 15 November 1999 di bawah pentadbiran Kementerian Perdagangan dalam Negeri dan Hal Ehwal Pengguna (KPDNHEP). TTPM mendengar dan mengadili semua kes berkaitan dengan tuntutan yang difailkan oleh pengguna yang tertakluk di bawah peruntukan tersebut.

Sebelum penubuhan TTPM, sebarang ganti rugi dan pertikaian yang melibatkan pengguna dibawa ke mahkamah sivil. Walau bagaimanapun, mahkamah melibatkan prosedur yang rumit, kos yang tinggi, dan tempoh yang panjang untuk menyelesaikan sesuatu pertikaian (Azimon, 2015:186-188). Penubuhan Tribunal dapat memberikan penyelesaian dengan menyediakan kaedah alternatif yang berkesan dan mesra pengguna dalam dunia kepenggunaan. Kaedah ini membolehkan sebarang tuntutan dan pertikaian dapat diselesaikan secara efisien (Azimon, 2015: 186187).

Penggubalan Akta Perlindungan Pengguna 1999 dan penubuhan TTPM merupakan inisiatif yang diharapkan oleh pengguna daripada pihak kerajaan. Usaha ini memperlihatkan bahawa isu berhubung penindasan terhadap hak pengguna termasuk dalam agenda penting negara (Azimon, 2015: 184). Penggubalan akta ini juga memperlihatkan keseriusan pihak berkuasa untuk memperbaik kelemahan kerangka undang-undang 
sebelum ini agar dapat memberikan jaminan perlindungan kepada pengguna sebaik-baiknya (Azimon, 2015: 184). Artikel ini menganalisis cara pertikaian yang dijalankan di TTPM dalam usaha mendepani isu-isu kepenggunaan di Malaysia bagi melihat cara TTPM membantu pengguna mendapatkan tebus rugi dengan berteraskan perundangan.

\section{PENUBUHAN TTPM: MEDIUM TEBUS RUGI KEPADA PENGGUNA}

Bertepatan dengan hasrat kerajaan dan aspirasi negara untuk menggalakkan perdagangan sihat serta membanteras segala bentuk penindasan, penggubalan dan penguatkuasaan undang-undang, maka TTPM berorientasikan perlindungan pengguna diwujudkan di kebanyakan negara termasuklah Malaysia bagi melindungi hak dan kepentingan pengguna. Namun begitu, didapati kebanyakan perundangan memberatkan aspek hukuman dan pencegahan sematamata. Terdapat keperluan kepada suatu mekanisme tebus rugi bagi pengguna yang terkilan untuk mendapatkan pampasan daripada peniaga secara kos efektif dengan jalan penyelesaian yang cepat. Bagi menyahut laungan agenda perjuangan pengguna, Akta Perlindungan Pengguna 1999 (Akta 599) telah digubal bagi memenuhi tiga tujuan utama, iaitu, (i) mengadakan peruntukan bagi perlindungan pengguna, (ii) penubuhan Majlis Penasihat Pengguna Negara, dan (iii) penubuhan Tribunal Tuntutan Pengguna (Mohamad Fazli, 2014: 102).

Penubuhan badan bebas untuk mendengar dan mengadili tuntutan pengguna, iaitu Tribunal Tuntutan Pengguna adalah di bawah peruntukan Seksyen 85 Bahagian XII Akta Perlindungan Pengguna 1999 di bawah pentadbiran Kementerian Perdagangan dalam Negeri dan Hal Ehwal Pengguna (KPDNHEP). Sebelum penubuhannya, sebarang remedi oleh seseorang pengguna terhadap seseorang peniaga dibawa ke mahkamah sivil (Muhammad Shariff, 2011). Ketiadaan mekanisme penyelesaian pertikaian yang berkesan dalam arena perdagangan dilihat sebagai salah satu punca kelemahan perundangan perlindungan pengguna sebelum 1999. Tribunal Tuntutan Pengguna Malaysia yang telah dikuatkuasakan pada 15 November 1999 sebagai mekanisme alternatif bagi memudahkan pengguna mendapat akses keadilan boleh dianggap sebagai suatu pencapaian dalam pembangunan undang-undang perlindungan pengguna di Malaysia (Naemah \& Elistina, 2010, 171). 
TTPM merupakan mekanisma yang diperlukan sebagai medium untuk mendapatkan keadilan di luar sistem kehakiman (Azimon, Sakina, Ismail, Rahmah, Shamsudin, Kartini \& Muhammad Rizal, 2011: 231-232). Walaupun masih mirip kepada sistem mahkamah dari segi pemfailan kes, TTPM memudahkan pengguna untuk mendapatkan keadilan. Berbanding dengan mahkamah sivil, prosedur dan formalitinya lebih ringkas, mudah, cepat dan mesra pengguna. Hanya RM5 sahaja bayaran dikenakan kepada pengguna untuk mendaftarkan kes dan aduan mereka. Selain itu, proses pendengaran yang jauh lebih ringkas berbanding dengan mahkamah sivil. Fokus TTPM hanya kepada penyelesaian pertikaian dalam kes melibatkan pengguna dengan jumlah tuntutan tidak melebihi RM25 000.

Prosedurnya juga ringkas yang memberikan jaminan bahawa sesuatu kes itu mestilah diselesaikan dalam masa 60 hari dari hari pertama kes itu didengar di hadapan presiden tribunal. Tiap-tiap keputusan yang dibuat disifatkan sebagai perintah dan boleh dikuatkuasakan oleh mana-mana pihak sama seperti prosiding yang dibuat di Mahkamah Majistret. Keputusan TTPM ini muktamad dan mengikat pihak-pihak yang bertikai. Sebarang rayuan kes terhadap keputusan yang dibuat oleh presiden tribunal adalah tidak dibenarkan sama sekali. Keputusan yang dibuat oleh presiden tribunal dikenali sebagai "award". Setiap award yang dibuat hendaklah dipatuhi dalam masa 14 hari dari tarikh award dibuat. Sekiranya terdapat pihak yang gagal mematuhi award tersebut dalam masa yang ditetapkan, pihak itu dikira telah melakukan kesalahan jenayah dan jika sabit kesalahan, bagi kesalahan pertama boleh didenda tidak melebihi RM5000 atau penjara tidak melebihi dua tahun atau kedua-duanya sekali (Azimon, 2015: 286-287).

\section{PENYELESAIAN PERTIKAIAN KES DI TRIBUNAL TUNTUTAN PENGGUNA MALAYSIA}

\section{Prosedur Pemfailan dan Pendaftaran Kes}

Sebelum sesuatu prosiding kes bermula, Pihak Yang Menuntut, iaitu istilah yang digunakan di mahkamah tribunal terhadap pihak yang ingin memfailkan sesuatu tuntutan, dikehendaki memfailkan tuntutan melalui borang yang telah ditetapkan di kaunter TTPM di seluruh Malaysia, iaitu 
tempat Pihak Yang Menuntut bermastautin. ${ }^{3}$ Pemfailan kes boleh dibuat secara fizikal, iaitu hadir di mana-mana pejabat TTPM di seluruh negara atau boleh dibuat pemfailan secara atas talian melalui e-tribunal, di laman rasmi TTPM. Perkara yang ingin dituntut tidak semestinya dalam bentuk wang. Tuntutan terbahagi kepada "3r", "repair, replace atau refund", iaitu tebus rugi dalam bentuk wang ringgit, mengganti atau membaiki semula barangan atau perkhidmatan yang diperoleh (Akta 599). Misalnya, barang tersebut boleh dibaik pulih, maka Pihak Yang Menuntut boleh meminta agar barangan tersebut dibaik pulih oleh Pihak Penentang. ${ }^{4}$ Jika barangan tersebut boleh diganti, maka Pihak Yang Menuntut boleh memohon untuk diganti sama ada dengan barang yang sama atau seakan-akan sama, seperti yang dipersetujui oleh kedua-dua belah pihak. ${ }^{5}$ Jika tidak, Pihak Yang Menuntut boleh memohon untuk tebus rugi dalam jumlah yang tidak melebihi RM25 000. ${ }^{6}$ Namun begitu, dalam kebanyakan kes, Pihak Yang Menuntut lebih berminat atau lebih cenderung memilih tebus rugi dalam bentuk wang ringgit selagi tidak melebihi RM25 000, ${ }^{7}$ serta tidak mendengar perkara di luar bidang kuasanya misalnya perkara berkaitan dengan wasiat dan tanah (Akta 599).

Ringkasnya, terdapat dua kategori tuntutan kes yang boleh difailkan di tribunal, iaitu dari aspek pembelian barang dan perkhidmatan. Contoh pembelian barang yang selalu dibawa ke tribunal termasuklah telefon bimbit, barangan elektronik, perabot dan kereta. Tuntutan difailkan atas pelbagai faktor, iaitu barang yang dibeli tidak berkualiti, barang yang dibeli tidak tulen atau asli atau rosak sedangkan baru sahaja dibeli. Untuk kategori perkhidmatan pula, contoh yang dapat dilihat ialah kes

3 Kaunter Pemfailan Kes di TTPM, Putrajaya.

4 TTPM-WPPJ (P)-005-2018.

5 TTPM-WPPJ (P)-013-2018.

6 Wan Rufaidah binti Dato' Haji Wan Omar (Pengerusi dan Presiden TTPM), dalam temu bual dengan pengkaji, 5 Oktober 2018 dan pemerhatian di dalam Mahkamah TTPM, Putrajaya, 9 Oktober 2018. Pengkaji telah mendapatkan kebenaran secara bertulis terlebih dahulu melalui borang persetujuan untuk menggunakan nama Responden dalam penerbitan.

7 Noorhasni binti Ahmad (Penolong Pegawai Undang-undang, Ketua Seksyen Pendengaran Kes dan Nasihat Perundangan, TTPM, Putrajaya), dalam temu bual dengan pengkaji, 9 Oktober 2018, berdasarkan fail-fail kes di TTPM, Putrajaya, dan pemerhatian di dalam Mahkamah TTPM, Putrajaya, 9 Oktober 2018.Pengkaji telah mendapatkan kebenaran secara bertulis terlebih dahulu melalui borang persetujuan untuk menggunakan nama Responden dalam penerbitan. 
penipuan perkhidmatan pakej umrah, pelancongan, pengubahsuaian rumah, bengkel kereta serta agensi pembantu rumah. Tuntutan dalam kategori ini pula atas pelbagai faktor, antaranya termasuklah penipuan pakej yang disediakan melanggar terma dan perjanjian yang telah dibuat, perkhidmatan yang diberikan tidak berpadanan dengan bayaran yang dibuat, pengguna berhadapan dengan masalah yang lebih teruk setelah mendapat perkhidmatan yang disediakan, tidak menerima perkhidmatan yang dijanjikan setelah bayaran dibuat serta barang yang dihantar untuk dibaiki hilang dalam simpanan pekedai. ${ }^{8}$ Tuntutan kes yang difailkan pula perlulah berada dalam senarai bidang kuasa TTPM seperti yang telah ditetapkan undang-undang berdasarkan seksyen 98 (1) tertakluk pada seksyen 99 dan 100 APP 1999 (Akta 599) dan mengikut prosedur yang telah ditetapkan.

Berdasarkan pemerhatian yang dilakukan, proses pemfailan dan pendaftaran setiap tuntutan kes yang difailkan adalah mudah dan mesra pengguna. Pengguna boleh menggunakan dua platform yang disediakan, iaitu sama ada hadir sendiri di ibu pejabat TTPM atau secara atas talian untuk memfailkan tuntutan kes. Bayaran yang dikenakan pula sangat murah serta tempoh bagi pendaftaran kes pula cepat. Pendengaran kes pula bermula sebaik sahaja serahan borang dibuat oleh pihak-pihak pada waktu yang ditetapkan. Ketiga-ketiga item ini, iaitu mudah, murah dan cepat mampu menarik para pengguna untuk bertindak memfailkan kes di TTPM berbanding di mahkamah sivil memandangkan prosedurnya yang lebih ringkas dan tidak merumitkan serta tidak membebankan dari segi kos.

Selain itu, penggunaan borang yang ditetapkan pula dapat memudahkan proses tuntutan kes dan menjadi rujukan kepada pihak-pihak yang terlibat serta sebagai rekod kepada TTPM. Borang ini juga penting untuk membolehkan penilaian yang wajar dapat dibuat oleh Presiden TTPM ketika membuat keputusan. Peraturan penggunaan jenis borang dan maklumat yang diisi sangat dititikberatkan oleh pihak TTPM. Segala keputusan yang dibuat bergantung pada maklumat yang terdapat dalam borang yang telah diisi oleh pihak-pihak yang terlibat. Pembahagian tiga jenis tebus rugi yang boleh dituntut juga memudahkan Pihak Yang Menuntut untuk memilih jenis tebus rugi yang bersesuaian dan munasabah dengan barang yang telah dibeli atau perkhidmatan yang diterima, serta melancarkan lagi proses penyelesaian kes di TTPM.

8 Berdasarkan pemerhatian yang dijalankan di Mahkamah TTPM, Putrajaya dan penelitian terhadap fail-fail kes di TTPM, Putrajaya, 9 Oktober 2018. 
Walaupun proses pendaftaran dan pemfailan kes di TTPM mudah dan ringkas, namun masih terdapat sebilangan pengguna yang tidak memahami prosedur tersebut dengan baik. Misalnya, penggunaan borangborang dan maklumat yang perlu diisi. Oleh itu, perhatian perlu diberikan tentang perkara ini supaya prosedur dapat dijelaskan dan disampaikan dengan baik kepada pengguna, iaitu masyarakat awam yang terdiri daripada pelbagai latar belakang. Perhatian khususnya diberikan kepada pengguna dari luar bandar atau pedalaman. Perkara ini penting kerana usaha ini dapat membantu presiden mengeluarkan award secepat mungkin bagi menjimatkan masa dan kos pihak-pihak yang terlibat untuk hadir ke TTPM jika segala prosedur dapat dipatuhi dengan baik oleh mereka.

\section{Tatacara Serahan Borang-borang Berkaitan Sebelum, Semasa dan Selepas Prosiding Kes Bermula}

Sebelum pendengaran kes bermula, Pihak Yang Menuntut hendaklah menyerahkan sesalinan Penyata Tuntutan kepada Pihak Penentang untuk makluman dan tindakan selanjutnya seperti yang telah ditetapkan dalam peruntukan undang-undang (Akta 599, Peraturan-peraturan Perlindungan Pengguna TTPM 1999). Cara serahan Penyata Tuntutan di mahkamah tribunal berbeza daripada mahkamah sivil kerana Pihak Yang Menuntut perlu menyerahkan tuntutannya sendiri kepada Pihak Penentang kerana tidak boleh diwakili oleh peguam. Tatacara ini memberikan kelebihan kepada pengguna kerana tidak perlu mengeluarkan kos yang besar untuk diwakili peguam. Namun begitu, prosedur serahan hendaklah dipatuhi seperti yang ditetapkan untuk kepentingan pihak-pihak terlibat, walaupun dilihat seakan-akan sama seperti di mahkamah sivil.

Serahan Penyata Tuntutan tersebut boleh dilakukan melalui kaedah utama, iaitu penyerahan secara kendiri. Pihak Yang Menuntut hendaklah menyerahkan sendiri Borang 1 atau Penyata Tuntutan kepada Pihak Penentang di alamat yang diperincikan seperti dalam Borang 1 tersebut dan hendaklah diterima oleh Pihak Penentang. Borang 1 ini hendaklah diserahkan kepada Pihak Penentang supaya Pihak Penentang dapat menjawab Penyata Tuntutan tersebut dalam masa 14 hari sebelum tarikh pendengaran kes bermula. ${ }^{9}$

9 Noorhasni binti Ahmad (Penolong Pegawai Undang-undang, Ketua Seksyen Pendengaran Kes dan Nasihat Perundangan, TTPM, Putrajaya), dalam temu bual dengan pengkaji, 9 Oktober 2018. 
Jika Pihak Penentang merupakan sebuah syarikat, maka serahan tersebut bolehlah diserahkan kepada pengarah, pengurus, setiausaha atau pegawai lain yang seumpamanya dalam syarikat itu. Borang 1 tersebut hendaklah ditandatangani oleh pihak yang menerima, berserta cop rasmi syarikat, nama dan tarikh sebagai bukti penerimaan telah diterima oleh Pihak Penentang dan telah sempurna diserahkan oleh Pihak Yang Menuntut. ${ }^{10}$ Berdasarkan Peraturan 15, serahan dokumen tersebut hendaklah kepada orang tersebut atau serah tinggal kepada orang tersebut. Orang lain tidak boleh mengambil atau mewakili serta menandatangani dokumen tersebut. ${ }^{11}$

Jika Pihak Penentang, sama ada individu atau syarikat, dengan sengaja enggan atau tidak mahu menerima serahan dokumen tersebut atau enggan memberikan kerjasama, maka Borang 1 tersebut boleh ditinggalkan berhampiran dengan Pihak Penentang, dan Pihak Yang Menuntut boleh membuat akuan sumpah berserta afidavit penyampaian yang menyatakan bahawa serahan telah dibuat, tetapi Pihak Penentang enggan menerima serahan tersebut. ${ }^{12}$

Walaupun tribunal memberikan kelonggaran kepada pengguna untuk melakukan tindakan seperti yang dinyatakan, akan tetapi hal ini akan menimbulkan kesukaran kepada pengguna apabila award dikeluarkan oleh presiden tribunal tetapi gagal dipatuhi oleh Pihak Penentang. Oleh itu, dalam isu ini, tribunal menyarankan kepada Pihak Yang Menuntut supaya menggunakan kaedah penyampaian secara kad kuning atau serahan secara surat berdaftar berbayar melalui pejabat pos kepada individu atau syarikat yang terlibat. Proses ini melibatkan kos yang rendah dan tidak membebankan pengguna atau Pihak Yang Menuntut. ${ }^{13}$

Melalui kaedah ini, Pihak Yang Menuntut boleh memeriksa sama ada serahan telah sempurna atau tidak kepada Pihak Penentang melalui atas talian, dan bukti penyerahan tersebut akan diserahkan kepada Pihak

10 Noorhasni binti Ahmad (Penolong Pegawai Undang-undang, Ketua Seksyen Pendengaran Kes dan Nasihat Perundangan, TTPM, Putrajaya), dalam temu bual dengan pengkaji, 9 Oktober 2018.

11 Noorhasni binti Ahmad (Penolong Pegawai Undang-undang, Ketua Seksyen Pendengaran Kes dan Nasihat Perundangan, TTPM, Putrajaya), dalam temu bual dengan pengkaji, 9 Oktober 2018.

12 Wan Rufaidah binti Dato' Haji Wan Omar (Pengerusi dan Presiden TTPM), dalam temu bual dengan pengkaji, 5 Oktober 2018.

13 Noorhasni binti Ahmad (Penolong Pegawai Undang-undang, Ketua Seksyen Pendengaran Kes dan Nasihat Perundangan, TTPM, Putrajaya), dalam temu bual dengan pengkaji, 9 Oktober 2018, Kaedah-Kaedah Mahkamah 2012 [P.U. (A) 205/2012]. 
Yang Menuntut oleh penghantar sama ada berjaya atau tidak dan boleh digunakan sebagai bukti serahan. ${ }^{14}$

Seterusnya, jika pendengaran kes telah bermula dan keputusan berjaya dicapai atas persetujuan atau perbincangan kedua-dua belah pihak tanpa perlu kepada perbicaraan, maka award akan dikeluarkan oleh presiden tribunal dalam Borang $9,{ }^{15}$ manakala jika keputusan dikeluarkan oleh presiden tribunal tanpa persetujuan kedua-dua pihak tetapi dengan kehadiran kedua-dua pihak, maka award akan dikeluarkan melalui Borang 10. ${ }^{16}$ Presiden juga terlebih dahulu akan menggalakkan kedua-dua pihak hadir untuk berbincang terlebih dahulu secara baik di luar mahkamah supaya suatu keputusan yang baik dapat dicapai. Namun begitu, jika kedua-dua pihak enggan bertolak ansur maka presiden akan mendengar atau mengambil keterangan daripada kedua-dua pihak secara saksama untuk mengemukakan hujah dan pembuktian masing-masing sebelum membuat keputusan. ${ }^{17}$

Dalam kes Pihak Penentang tidak hadir, presiden akan melihat penyerahan Borang 1 atau Penyata Tuntutan sama ada telah disempurnakan oleh Pihak Yang Menuntut atau tidak. Jika penyata tuntutan telah dilaksanakan oleh Pihak Yang Menuntut, dan presiden berpuas hati dengannya, serta Pihak Penentang tidak hadir, maka kes akan diteruskan tanpa kehadiran sebelah pihak dan award akan dikeluarkan dalam Borang 8 , iaitu kes tersebut berjalan sebelah pihak atau ex-parte.$^{18}$ Seterusnya, jika pihak penuntut pula tidak hadir semasa prosiding berlangsung, manakala Pihak Penentang hadir, maka kes tersebut akan dibuang. ${ }^{19}$ Setelah award

14 TTPM-WPPJ (P)-016- 2018, TTPM-WPPJ (P)-024-2018.

15 TTPM-WPPJ (P)-004-2018, TTPM-WPPJ (P)-005-2018, TTPM-WPPJ (P)-006-2018.

16 Berdasarkan pemerhatian di dalam Mahkamah TTPM, Putrajaya (TTPM-WPPJ (P)005-2018), (TTPM-WPPJ (P)-008-2018), 9 Oktober 2018.

17 Berdasarkan pemerhatian di dalam Mahkamah TTPM, Putrajaya (TTPM-WPPJ (P)005-2018), (TTPM-WPPJ (P)-006-2018), (TTPM-WPPJ (P)-008-2018), 9 Oktober 2018.

18 Berdasarkan pemerhatian di dalam Mahkamah TTPM, Putrajaya (TTPM-WPPJ (P)001-2018), (TTPM-WPPJ (P)-002-2018), (TTPM-WPPJ (P)-003-2018), (TTPM-WPPJ (P)-007-2018), (TTPM-WPPJ (P)-009-2018), 9 Oktober 2018.

19 Berdasarkan pemerhatian di dalam Mahkamah TTPM, Putrajaya (TTPM-WPPJ (P)004-2018), 9 Oktober 2018. 
dikeluarkan, maka Pihak Penentang akan diberi tempoh masa 14 hari untuk melaksanakan award tersebut dari tarikhnya dikeluarkan. Pengiraan masa tersebut bermula pada keesokan harinya, tidak termasuk hari tidak bekerja dan cuti umum (Akta 599). ${ }^{20}$

Seterusnya, jika award tersebut gagal dipatuhi oleh Pihak Penentang selepas tempoh 14 hari, maka Pihak Yang Menuntut boleh membuat aduan kepada pihak penguat kuasa untuk tindakan lanjut. Pihak penguat kuasa, iaitu Pegawai Penyiasat KPDNHEP akan membuka kertas siasatan dan mendapatkan segala dokumen berkaitan. Sekiranya pegawai penyiasat berpuas hati dengan cara serahan award melalui borang bukti penyerahan award jika pihak tersebut tidak hadir, atau dalam keadaan lain keduadua pihak hadir dan award telah pun diterima, maka tindakan untuk pendakwaan terhadap Pihak Penentang akan dibuat atas kesalahan tersebut sahaja, bukan arahan untuk membayar award tersebut kepada Pihak Yang Menuntut (Akta 599). ${ }^{21}$

Dalam keadaan apabila Pihak Penentang tidak hadir semasa prosiding berlangsung, maka perintah atau award akan dikeluarkan dalam Borang 8 kerana keputusan dibuat atas kehadiran sebelah pihak atau ex-parte. Award tersebut perlu diserahkan secara kendiri oleh Pihak Yang Menuntut terhadap Pihak Penentang dan borang bukti penyerahan award perlu diisi dan ditandatangani oleh kedua-dua pihak sebagai bukti penyerahan dan penerimaan award, dan penyerahan award tidak boleh diserahkan kepada orang lain. Jika tidak diserahkan kepada Pihak Penentang, maka tempoh 14 hari tersebut tidak dikira dan tidak berjalan, serta pihak penguat kuasa tidak akan meneruskannya ke peringkat pendakwaan untuk tindakan lanjut kerana tidak mematuhi prosedur penyerahan sekiranya award tidak dipatuhi oleh Pihak Penentang. Di sini, jika usaha untuk menyerahkan award tersebut tidak berjaya dilakukan secara kendiri dan tidak mendapat kerjasama daripada Pihak Penentang, cara yang sama semasa penyerahan Penyataan Tuntutan tidak boleh digunakan. ${ }^{22}$ Hal ini dikatakan demikian kerana

20 Noorhasni binti Ahmad (Penolong Pegawai Undang-undang, Ketua Seksyen Pendengaran Kes dan Nasihat Perundangan, TTPM, Putrajaya), dalam temu bual dengan pengkaji, 9 Oktober 2018.

21 Noorhasni binti Ahmad (Penolong Pegawai Undang-undang, Ketua Seksyen Pendengaran Kes dan Nasihat Perundangan, TTPM, Putrajaya), dalam temu bual dengan pengkaji, 9 Oktober 2018.

22 Noorhasni binti Ahmad (Penolong Pegawai Undang-undang, Ketua Seksyen Pendengaran Kes dan Nasihat Perundangan, TTPM, Putrajaya), dalam temu bual dengan pengkaji, 9 Oktober 2018. 
berhubung kait dengan isu penguatkuasaan award dan prosedurnya adalah lebih ketat kerana melibatkan bidang kuasa Mahkamah Majistret Jenayah (Kelas Pertama). Penyerahan tersebut hanya boleh dilakukan secara kendiri kepada Pihak Penentang, dan perkara yang menjadi masalah di sini ialah penyerahan award kepada individu.

Dalam isu award yang tidak dipatuhi oleh Pihak Penentang, award tersebut tiada tarikh tertentu atau luput, dan tetap berjalan selagi tidak dipatuhi oleh Pihak Penentang. ${ }^{23}$

Seterusnya, Borang 12 akan diserahkan kepada presiden dan bergantung pada keputusan presiden sama ada menerima atau menolak alasan tersebut. Kebiasaannya dalam situasi ini, presiden akan membenarkan permohonan tersebut dan perbicaraan terhadap tuntutan tersebut didengar semula dengan kehadiran kedua-dua belah pihak berserta keterangan dan pembuktian yang dikemukakan. Dalam keadaan ini, sama ada suatu keputusan baharu akan dikeluarkan oleh tribunal yang menandakan bahawa presiden menerima Borang 12 tersebut tetapi keputusan dalam Borang 8 tersebut dikekalkan terhadap Pihak Penentang ataupun keputusan Borang 8 dibatalkan kerana keputusan baharu dikeluarkan dalam Borang 10. ${ }^{24}$

Dalam situasi pihak-pihak tidak berpuas hati terhadap keputusan yang telah dikeluarkan oleh presiden sama ada Pihak Yang Menuntut atau Pihak Penentang, maka rayuan boleh dibuat kepada Mahkamah Tinggi Malaya di Kuala Lumpur (Bahagian Rayuan dan Kuasa-Kuasa Khas) untuk menyemak semula keputusan yang telah dikeluarkan oleh presiden. Kebiasaannya, pihak yang sering kali tidak berpuas hati dan membuat rayuan kepada mahkamah ini ialah Pihak Penentang. ${ }^{25}$ Seterusnya, jika tidak terdapat sebarang isu berkenaan dengan borang-borang tersebut, maka setiausaha tribunal akan menetapkan satu hari, tarikh dan masa pendengaran kes pada borang yang difailkan untuk diserahkan kepada

23 Noorhasni binti Ahmad (Penolong Pegawai Undang-undang, Ketua Seksyen Pendengaran Kes dan Nasihat Perundangan, TTPM, Putrajaya), dalam temu bual dengan pengkaji, 9 Oktober 2018.

24 Noorhasni binti Ahmad (Penolong Pegawai Undang-undang, Ketua Seksyen Pendengaran Kes dan Nasihat Perundangan, TTPM, Putrajaya), dalam temu bual dengan pengkaji, 9 Oktober 2018.

25 Noorhasni binti Ahmad (Penolong Pegawai Undang-undang, Ketua Seksyen Pendengaran Kes dan Nasihat Perundangan, TTPM, Putrajaya), dalam temu bual dengan pengkaji, 9 Oktober 2018. 
pihak-pihak berkenaan. ${ }^{26}$ Notis pendengaran akan dikeluarkan oleh tribunal dalam Borang 4 dan diserahkan kepada pihak-pihak terlibat.

Dalam perkara tatacara serahan borang-borang berkaitan sepanjang kes berjalan, dapat diperhatikan bahawa prosedurnya lebih ringkas dan melibatkan kos yang rendah berbanding tuntutan kes di mahkamah sivil yang melibatkan kos yang lebih tinggi kerana pihak-pihak terlibat tidak perlu menggunakan khidmat peguam untuk mewakili mereka bermula dari tarikh pendaftaran kes hingga pada hari pendengaran kes di hadapan presiden. Penggunaan borang-borang yang terlibat pula bergantung pada situasi dan keadaan pihak-pihak serta keperluan kes. Turutan penggunaan borang yang digunakan perlu diikuti dan dipatuhi supaya melancarkan lagi proses tuntutan kes.

Tatacara atau kaedah serahan yang diberikan perlu diikuti oleh pihak yang terlibat seperti yang telah dijelaskan supaya kes dapat berjalan dengan baik kerana setiap borang tersebut mengandungi maklumat yang penting berkaitan dengan kes yang dituntut dan merupakan formaliti yang perlu dilalui oleh setiap pihak tanpa pengecualian. Jika kaedah serahan tidak dibuat berdasarkan prosedur yang betul, maka hal ini boleh mendatangkan kesan terhadap tuntutan kes dan tindakan yang boleh diambil terutamanya dalam proses menguatkuasakan award sekiranya tidak dilaksanakan oleh Pihak Penentang.

Walaupun terdapat garis panduan yang telah disediakan oleh TTPM dalam kaedah serahan borang-borang berkaitan kes, namun wujud isu berkaitan dengan tatacara serahan yang perlu ditambah baik oleh TTPM. Untuk memudahkan Pihak Yang Menuntut menyerahkan borang berkaitan kepada Pihak Penentang yang enggan memberikan kerjasama terutamanya dalam isu serahan award dalam Borang 8 bagi kes yang berjalan secara sebelah pihak atau ex-parte, kaedah serahan Borang 8 tersebut perlu diberikan alternatif lain selain serahan secara kendiri. Pihak Yang Menuntut akan menghadapi kesukaran sekiranya Pihak Penentang enggan memberikan kerjasama, sedangkan bukti serahan award kepada Pihak Penentang perlu dikemukakan kepada Pihak Penguatkuasa KPDNHEP.

26 Noorhasni binti Ahmad (Penolong Pegawai Undang-undang, Ketua Seksyen Pendengaran Kes dan Nasihat Perundangan, TTPM, Putrajaya), dalam temu bual dengan pengkaji, 9 Oktober 2018. 


\section{Situasi dan Prosedur setelah Pendengaran Kes Bermula di Mahkamah Tribunal}

Di mahkamah sivil, dua orang pegawai yang berada di hadapan mahkamah dipanggil sebagai jurubahasa, tetapi di Mahkamah TTPM dua orang pegawai tersebut dikenali sebagai penolong setiausaha bagi presiden di mahkamah TTPM. Mereka ditugaskan untuk menjadi pembantu kepada presiden di dalam mahkamah tribunal semasa prosiding kes sedang berlangsung dan berperanan sebagai orang tengah antara pihak yang bertikai dengan presiden dalam urusan penyerahan dokumen, membantu menetapkan tarikh jika prosiding ditangguhkan pada satu masa yang lain serta menaip keterangan antara pihak bertikai dengan presiden. ${ }^{27}$ Selain itu, tempat prosiding pendengaran kes dijalankan dikenali sebagai "mahkamah tribunal" dan kes yang akan didengar pula dibahagikan mengikut jumlah kes. Presiden yang bertugas mengikut giliran masing-masing pada hari, masa dan mahkamah tribunal yang telah ditetapkan yang disusun oleh Ketua Seksyen Pendengaran Kes dan Nasihat Perundangan. ${ }^{28}$

Perbezaan lain antara mahkamah TTPM dengan mahkamah sivil ialah tiada polis mahkamah, kecuali apabila terdapat keperluan yang mendesak. ${ }^{29}$ Jika terdapat isu atau kes besar atau terdapat pihak-pihak yang bertikai dilihat bersikap tidak patut dan berkelakuan di luar kawalan daripada awal pendaftaran kes sehingga prosiding bermula, maka para pegawai tribunal yang terlibat sudah boleh mengagak atau menjustifikasikan prosiding kes pada hari yang ditetapkan memerlukan bantuan pegawai atau pihak berkuasa untuk mengawal keadaan agar prosiding di dalam mahkamah TTPM berjalan dengan lancar tanpa sebarang kekecohan atau provokasi melampau daripada pihak-pihak yang bertikai sehingga mengganggu perjalanan kes. Oleh itu, pihak tribunal akan meminta bantuan Pihak Penguat kuasa dari KPDNHEP untuk membantu mengawal keadaan sepanjang prosiding kes berjalan, sekiranya perlu (Akta 599). ${ }^{30}$ Namun begitu, dalam kebanyakan kes, pengerusi sendiri dapat mengawal tingkah

27 Berdasarkan pemerhatian di dalam Mahkamah TTPM, Putrajaya, 9 Oktober 2018.

28 Noorhasni binti Ahmad (Penolong Pegawai Undang-undang, Ketua Seksyen Pendengaran Kes dan Nasihat Perundangan, TTPM, Putrajaya), dalam temu bual dengan pengkaji, 9 Oktober 2018.

29 Berdasarkan pemerhatian di dalam Mahkamah TTPM, Putrajaya, 9 Oktober 2018.

30 Noorhasni binti Ahmad (Penolong Pegawai Undang-undang, Ketua Seksyen Pendengaran Kes dan Nasihat Perundangan, TTPM, Putrajaya), dalam temu bual dengan pengkaji, 9 Oktober 2018. 
laku pihak-pihak dan mengawal situasi sekiranya perbalahan berlaku dan menasihati pihak-pihak supaya bersikap wajar walaupun di mahkamah tribunal. Sungguhpun begitu, bagi tujuan penambahbaikan, keperluan untuk mempunyai anggota yang mengawal situasi di mahkamah TTPM adalah perkara yang baik supaya pihak-pihak bersikap wajar di hadapan presiden dan menghormati mahkamah tribunal.

\section{Kaedah Penyelesaian Kes di Tribunal}

\section{(1) Panduan Presiden sebelum Membuat Keputusan}

Apabila pendengaran kes bermula di mahkamah tribunal, pihak-pihak berhak mengemukakan sebarang keterangan, memanggil mana-mana saksi, mengemukakan bukti dalam bentuk dokumen, rekod atau benda bagi menyokong tuntutan. Kesemua keterangan dan maklumat perlu dibawa untuk diserahkan kepada presiden sebagai rujukan pihak-pihak untuk mengukuhkan lagi sesuatu tuntutan dan sebagai justifikasi kepada Presiden TTPM untuk membuat keputusan yang adil, wajar dan patut kepada pihak-pihak yang terlibat. ${ }^{31}$ Tanpa sebarang dokumen sokongan, boleh memberi implikasi atau kesan terhadap kes yang difailkan oleh Pihak Yang Menuntut, dan akan bergantung pada keputusan presiden sepenuhnya dan fakta kes. ${ }^{32}$ Sebelum kes bermula mereka (Pihak Yang Menuntut) telah diberikan penerangan oleh pegawai di bahagian kaunter pemfailan kes supaya membawa segala dokumen yang berkaitan.

Dalam sesetengah kes, presiden tribunal melihat dan meneliti terlebih dahulu kepentingan sesuatu dokumen sebelum keputusan dibuat. ${ }^{33}$ Jika presiden berpuas hati dengan dokumen dan bukti yang ada dan boleh membuat keputusan berdasarkan bukti sedia ada, walaupun Pihak Penentang gagal menyediakan dokumen tambahan yang mungkin diperlukan oleh presiden untuk diteliti, atau Pihak Yang Menuntut pada hari prosiding berlangsung menyatakan ada dokumen tambahan lain yang boleh menyokong kepada tuntutannya, maka presiden tidak akan menangguhkan

31 Berdasarkan pemerhatian pengkaji di dalam Mahkamah TTPM, Putrajaya, 9 Oktober 2018.

32 Wan Rufaidah binti Dato' Haji Wan Omar (Pengerusi dan Presiden TTPM), dalam temu bual dengan pengkaji, 5 Oktober 2018.

33 Wan Rufaidah binti Dato' Haji Wan Omar (Pengerusi dan Presiden TTPM), dalam temu bual dengan pengkaji, 5 Oktober 2018. 
kes tersebut dan terus membuat keputusan award. ${ }^{34}$ Sekiranya presiden tribunal mendapati terdapat kesukaran untuk memperoleh sesuatu dokumen penting, misalnya memerlukan proses tertentu atau melibatkan birokrasi yang banyak dan rumit, maka kes tersebut akan ditangguhkan kepada suatu masa yang wajar untuk memberi peluang kepada Pihak Yang Menuntut membuktikan kesnya dan presiden dapat membuat keputusan yang wajar bagi kedua-dua belah pihak. ${ }^{35}$ Terdapat sesetengah pihak tidak mengambil berat dan bersikap sambil lewa dengan tidak membawa sebarang bukti atau dokumen sokongan bagi kes mereka sehingga mengganggu perjalanan kes. $^{36}$ Hal ini terjadi kerana terdapat sebahagian pengguna mengambil mudah dengan menyatakan bahawa semua perkara tuntutan terdapat dalam telefon mudah alih. Keadaan ini menyukarkan pihak mahkamah dan pihak terlibat ketika membuat rujukan dan penelitian kes apabila prosiding telah bermula.$^{37}$ Kes tuntutan juga boleh ditolak sekiranya Pihak Yang Menuntut tidak mempunyai dokumen sokongan yang cukup seperti dakwaannya dalam Penyata Tuntutan. ${ }^{38}$

\section{Kaedah Penyelesaian Tebus Rugi}

Kaedah penyelesaian tebus rugi pula bergantung pada tuntutan Pihak Yang Menuntut, iaitu jika Pihak Yang Menuntut inginkan barang tersebut diganti dengan barang yang sama sekiranya terdapat jaminan atau warranty, dan jika perkara tersebut tidak dapat dipenuhi atau dibuat oleh Pihak Penentang, maka presiden akan menggantikan tuntutan tersebut kepada kaedah tebus rugi yang lain berdasarkan peruntukan undang-undang dan persetujuan pihak-pihak. ${ }^{39}$

34 Berdasarkan pemerhatian di dalam Mahkamah TTPM, Putrajaya, (TTPM-WPPJ (P)006-2018), 9 Oktober 2018.

35 Wan Rufaidah binti Dato' Haji Wan Omar (Pengerusi dan Presiden TTPM), dalam temu bual dengan pengkaji, 5 Oktober 2018.

36 Noorhasni binti Ahmad (Penolong Pegawai Undang-undang, Ketua Seksyen Pendengaran Kes dan Nasihat Perundangan, TTPM, Putrajaya), dalam temu bual dengan pengkaji, 9 Oktober 2018.

37 Noorhasni binti Ahmad (Penolong Pegawai Undang-undang, Ketua Seksyen Pendengaran Kes dan Nasihat Perundangan, TTPM, Putrajaya), dalam temu bual dengan pengkaji, 9 Oktober 2018.

38 Noorhasni binti Ahmad (Penolong Pegawai Undang-undang, Ketua Seksyen Pendengaran Kes dan Nasihat Perundangan, TTPM, Putrajaya), dalam temu bual dengan pengkaji, 9 Oktober 2018.

39 Berdasarkan pemerhatian di dalam Mahkamah TTPM, Putrajaya, 9 Oktober 2018, Akta Perlindungan Pengguna 1999 (Akta 599), Seksyen 112 (2). 
Namun begitu, pemberian award dalam bentuk tebus rugi wang tidak bermakna pihak penuntut akan mendapat jumlah seperti yang dimohon dalam pernyataan tuntutan. Hal ini bergantung pada keadaan tertentu misalnya berlaku pengurangan jumlah atas faktor tahun, masa penggunaan oleh Pihak Yang Menuntut, atau bayaran khidmat atau servis yang perlu dibelanjakan oleh Pihak Penentang dan keadaan barang tersebut semasa tuntutan itu dibuat. ${ }^{40}$ Presiden tribunal akan mengambil kira pelbagai aspek daripada kedua-dua belah pihak sebelum keputusan award dibuat. ${ }^{41}$

\section{Kaedah Penyelesaian Sesuatu Tuntutan}

Presiden juga meminta Pihak Yang Menuntut mengemukakan bukti atau keterangan yang boleh menyokong tuntutan tersebut seperti resit pembelian, surat penagihan yang dikeluarkan oleh pihak penjual kepada pihak pembeli atau invois, menunjukkan kerosakan yang terlibat. Jika seseuatu tuntutan berkaitan dengan kerja baik pulih sesuatu barang, maka laporan daripada pihak profesional seperti Quantity Surveyor (QS) diperlukan kerana peranannya yang sangat penting khususnya dalam bidang pengurusan kewangan projek pembinaan, ataupun sebut harga akan diminta oleh presiden untuk sokongan kes bagi membuat perbandingan dan menentukan award yang akan dikeluarkan (Akta 599). ${ }^{42}$

Dalam sesetengah keadaan, nilaian tidak boleh dibuat dengan mata kasar tetapi memerlukan pengesahan daripada individu yang berkelayakan. Selain itu, terdapat kes yang memerlukan presiden sendiri turun ke lapangan dan membuat penilaian, misalnya dalam kes ubah suai rumah dan baik pulih kenderaan di bengkel bagi melihat sendiri alat ganti atau cara bekerja berkenaan tuntutan kes. Perkara ini dibuat hanya sekiranya presiden tidak berpuas hati dengan keterangan yang diberikan dan akan menangguhkan kes ke suatu masa yang munasabah. ${ }^{43}$

40 Wan Rufaidah binti Dato' Haji Wan Omar (Pengerusi dan Presiden TTPM), dalam temu bual dengan pengkaji, 5 Oktober 2018 dan berdasarkan pemerhatian pengkaji di dalam Mahkamah TTPM, Putrajaya, 9 Oktober 2018.

41 Wan Rufaidah binti Dato' Haji Wan Omar (Pengerusi dan Presiden TTPM), dalam temu bual dengan pengkaji, 5 Oktober 2018 dan berdasarkan pemerhatian pengkaji di dalam Mahkamah TTPM, Putrajaya, 9 Oktober 2018.

42 Rujukan fail-fail kes di TTPM, Putrajaya dan pemerhatian di dalam Mahkamah TTPM, Putrajaya, 9 Oktober 2018.

43 Wan Rufaidah binti Dato' Haji Wan Omar (Pengerusi dan Presiden TTPM), dalam temu bual dengan pengkaji, 5 Oktober 2018. 
(4) Situasi dan Prosedur apabila Pendengaran Kes Bermula di Mahkamah Tribunal

Walaupun tribunal akan membantu dan membimbing Pihak Yang Menuntut cara atau prosedur untuk membuat representasi kes dan kaedah keterangan yang boleh dikemukakan, kerana sedar bahawa pengguna terdiri daripada orang awam yang tidak boleh diwakili peguam (Akta 599) dan tidak mempunyai pengetahuan undang-undang yang mendalam, akan tetapi tribunal dilihat tidak berat sebelah terhadap Pihak Penentang. Namun begitu, jika Pihak Penentang diwakili oleh Penasihat Undang-undang yang bekerja dan dibayar gaji sepenuh masa di syarikat mereka, presiden dilihat bersikap adil kepada Pihak Yang Menuntut serta keputusan yang dibuat wajar dan tidak menyebelahi mana-mana pihak kerana semuanya masih bergantung pada pembuktian dan keterangan yang dikemukakan (Akta 599). ${ }^{44}$ Jika Pihak Yang Menuntut belum dewasa atau seorang yang tidak berupaya, maka beliau boleh diwaliki oleh sahabat wakil atau penjaga yang sah (Akta 599). ${ }^{45}$

Selain itu, terdapat prosiding kes yang dimulakan tanpa kehadiran Pihak Penentang dan berjalan secara ex-parte setelah presiden tribunal berpuas hati bahawa serahan Penyata Tuntutan telah dibuat dengan sempurna oleh Pihak Yang Menuntut serta notis pendengaran telah diserahkan kepada pihak yang tidak hadir tersebut sewajarnya. Seterusnya keputusan juga akan dikeluarkan pada hari yang sama walaupun tanpa kehadiran Pihak Penentang, namun perlu disertakan dengan keterangan dan pembuktian yang boleh meyakinkan presiden (Akta 599). ${ }^{46}$

Selain itu, presiden juga akan merekodkan keputusan atau penyelesaian yang telah dibuat secara bertulis ${ }^{47}$ (Akta 599) serta menyatakan sebab dan

44 Berdasarkan pemerhatian di dalam Mahkamah TTPM, Putrajaya (TTPM-WPPJ (P)006-2018), 9 Oktober 2018, Wan Rufaidah binti Dato' Haji Wan Omar (Pengerusi dan Presiden TTPM), dalam temu bual dengan pengkaji, 5 Oktober 2018

45 Wan Rufaidah binti Dato' Haji Wan Omar (Pengerusi dan Presiden TTPM), dalam temu bual dengan pengkaji, 5 Oktober 2018

46 Berdasarkan pemerhatian di dalam Mahkamah TTPM, Putrajaya (TTPM-WPPJ (P)001-2018), (TTPM-WPPJ (P)-002-2018), (TTPM-WPPJ (P)-003-2018), (TTPM-WPPJ (P)-007-2018), (TTPM-WPPJ (P)-009-2018), 9 Oktober 2018.

47 Berdasarkan pemerhatian di dalam Mahkamah TTPM, Putrajaya, 9 Oktober 2018. 
alasan serta peruntukan undang-undang berkaitan dengn setiap keputusan award yang dikeluarkan untuk memberikan kepuasan kepada kedua-dua belah pihak berkenaan. Perekodan keputusan secara bertuli juga menjadi panduan kepada Hakim Mahkamah Tinggi Sivil jika semakan kehakiman dibuat oleh mana-mana pihak (Akta 599).$^{48}$ Selain itu, sebelum sesuatu prosiding kes bermula di mahkamah, pihak-pihak yang hadir dan terlibat dinasihati supaya bersedia lebih awal, peka, teliti dan bertanggungjawab terhadap kes yang dibawa di hadapan presiden. ${ }^{49}$ Misalnya, Pihak Yang Menuntut sudah maklum berkenaan dengan dokumen dan pembuktian berkaitan dengan kes yang perlu dibawa, mengetahui dengan mendalam rentetan kes, dan dapat menjawab persoalan yang diajukan oleh presiden berkaitan dengan kes tuntutan. ${ }^{50}$ Penyelesaian sesuatu kes bergantung pada bukti dan keterangan pihak-pihak. Kebiasaannya jika presiden telah berpuas hati dan yakin untuk membuat keputusan, maka kes dapat diselesaikan dalam masa satu hari sahaja dan award dapat dikeluarkan pada hari tersebut atau secepat mungkin seperti yang diperuntukkan oleh undang-undang. ${ }^{51}$

Begitu juga, jika pihak-pihak yang terlibat dapat mencapai kata sepakat dan persetujuan sebelum prosiding berlangsung atau semasa kes berlangsung pihak-pihak ingin menjalankan rundingan damai untuk mencapai kata sepakat berkenaan penyelesaian yang ingin dicapai, maka kes akan selesai dalam masa satu hari sahaja. ${ }^{52}$ Keputusan yang telah dikeluarkan oleh Presiden TTPM juga muktamad dan mengikat pihakpihak yang terlibat dalam sesuatu tuntutan (Akta 599).$^{53}$ Namun begitu, semakan kehakiman boleh dibuat untuk menimbang semula keputusan tersebut di Mahkamah Tinggi Sivil (Aturan 53 Kaedah-kaedah Mahkamah 2012).

Presiden TTPM juga akan menggalakkan pihak-pihak yang terlibat supaya berbincang di luar mahkamah dan memberikan ruang dan peluang

48 Wan Rufaidah binti Dato' Haji Wan Omar (Pengerusi dan Presiden TTPM), dalam temu bual dengan pengkaji, 5 Oktober 2018.

49 Noorhasni binti Ahmad (Penolong Pegawai Undang-undang, Ketua Seksyen Pendengaran Kes dan Nasihat Perundangan, TTPM, Putrajaya), dalam temu bual dengan pengkaji, 9 Oktober 2018.

50 Berdasarkan pemerhatian di dalam Mahkamah TTPM, Putrajaya, 9 Oktober 2018.

51 Berdasarkan pemerhatian di dalam Mahkamah TTPM, Putrajaya, 9 Oktober 2018.

52 Noorhasni binti Ahmad (Penolong Pegawai Undang-undang, Ketua Seksyen Pendengaran Kes dan Nasihat Perundangan, TTPM, Putrajaya), dalam temu bual dengan pengkaji, 9 Oktober 2018.

53 Berdasarkan pemerhatian di dalam Mahkamah TTPM, Putrajaya, 9 Oktober 2018. 
kepada mereka unuk mencapai penyelesaian yang terbaik (Akta 599). ${ }^{54}$ Galakan ini berdasarkan kepada Seksyen 107 yang menyarankan supaya presiden memberikan galakan kepada pihak-pihak untuk berbincang sama ada dengan bantuan presiden atau antara pihak-pihak sahaja bagi mencapai persetujuan secara baik (Akta 599). Kes juga boleh ditarik balik sekiranya kedua-dua pihak bersetuju untuk menyelesaikannya di luar mahkamah tribunal. ${ }^{55}$

Presiden juga meneliti kandungan fail tuntutan sebelum kes berjalan dan berdasarkan pengalaman, presiden tribunal boleh menjustifikasikan sama ada sesuatu kes itu boleh diselesaikan secara baik atau tidak. Jika sebaliknya, presiden sendiri yang akan membuat keputusan yang wajar bagi kes yang dituntut. ${ }^{56}$ Pihak tribunal juga berhadapan dengan pelbagai kerenah masyarakat misalnya ketidakpatuhan prosedur, iaitu sebelum, semasa dan selepas kes berjalan di mahkamah tribunal. Hal ini juga menyebabkan sedikit sebanyak menganggu kelancaran perjalanan kes sekali gus mencacatkan kewibawaan TTPM itu sendiri. ${ }^{57}$

Seterusnya, apabila prosiding kes telah bermula, maka tiada sebarang nasihat dari sudut perundangan atau perjalanan kes boleh diminta kepada presiden atau pegawai tribunal kerana perkara tersebut akan menimbulkan rasa kurang senang atau ketidakpuasan hati sebelah pihak yang lain, iaitu Pihak Penentang. Situasi tersebut akan menimbulkan prejudis atau ketidakadilan kepada satu pihak yang lain. Sebarang pertanyaan prosedur atau nasihat perundangan hendaklah diminta atau diambil sebelum prosiding kes bermula di dalam mahkamah tribunal. ${ }^{58}$

54 Berdasarkan pemerhatian di dalam Mahkamah TTPM, Putrajaya (TTPM-WPPJ (P)005-2018), (TTPM-WPPJ (P)-006-2018), (TTPM-WPPJ (P)-008-2018), 9 Oktober 2018.

55 Noorhasni binti Ahmad (Penolong Pegawai Undang-undang, Ketua Seksyen Pendengaran Kes dan Nasihat Perundangan, TTPM, Putrajaya), dalam temu bual dengan pengkaji, 9 Oktober 2018.

56 Wan Rufaidah binti Dato' Haji Wan Omar (Pengerusi dan Presiden TTPM), dalam temu bual dengan pengkaji, 5 Oktober 2018.

57 Wan Rufaidah binti Dato' Haji Wan Omar (Pengerusi dan Presiden TTPM), dalam temu bual dengan pengkaji, 5 Oktober 2018.

58 Wan Rufaidah binti Dato' Haji Wan Omar (Pengerusi dan Presiden TTPM), dalam temu bual dengan pengkaji, 5 Oktober 2018. 
Berdasarkan pemerhatian yang dibuat, kaedah penyelesaian di mahkamah TTPM bergantung pada maklumat yang terdapat dalam borang-borang yang difailkan oleh pihak-pihak yang terlibat. Maka, menjadi tanggungjawab pihak-pihak yang terlibat supaya butiran maklumat yang diberikan betul dan segala tuntutan yang dinyatakan hendaklah berserta keterangan dan pembuktian yang jelas dan boleh menyokong tuntutan yang difailkan sebagai panduan presiden sebelum membuat keputusan. Presiden juga melihat kaedah serahan borang-borang tersebut sama ada telah dibuat berdasarkan peraturan yang telah ditetapkan ataupun tidak.

Selain itu, terdapat tuntutan kes yang difailkan tidak diterima oleh presiden kerana tuntutan tersebut tidak berada dalam bidang kuasa TTPM, selain tidak mematuhi prosedur yang perlu dipatuhi seperti yang ditetapkan. Contohnya seperti Pihak Yang Menuntut tidak hadir semasa pendengaran berlangsung tanpa notis pemberitahuan kepada pihak TTPM sebab ketidakhadiran. Award dikeluarkan setelah presiden berpuas hati dengan segala keterangan yang telah dibuat serta pembuktian yang diberikan. Presiden memberikan peluang kepada pihak-pihak untuk menyuarakan ketidakpuasan hati masing-masing, mendengar kronologi sesuatu tuntutan kes satu persatu serta memberikan peluang pihak-pihak terlibat untuk membawa segala pembuktian yang berkaitan. Jika presiden tidak berpuas hati dengan keterangan yang dikemukakan, maka kes akan ditangguhkan pada hari yang lain supaya bukti yang berkaitan dapat dikemukakan untuk membantu presiden membuat keputusan yang munasabah. Award yang dikeluarkan oleh presiden pula bergantung pada pertimbangan presiden sebelum membuat keputusan dengan melihat dan meneliti keadaan barang yang telah digunakan serta perkhidmatan yang telah diterima. Presiden mempunyai budi bicara untuk mendengar sesuatu tuntutan kes. Jika presiden tidak berpuas hati dengan keterangan dan pembuktian yang dikemukakan, maka presiden sendiri yang boleh bertindak berdasarkan kuasa yang diberikan dan peruntukan undang-undang untuk mendapatkan maklumat bagi membuat penilaian berkaitan dengan kes sebelum membuat keputusan.

Dalam kebanyakan kes, pengguna lebih memilih tebus rugi dalam bentuk wang ringgit (tidak boleh melebihi RM25 000) kerana beranggapan penyelesaian ini lebih mudah dan tidak mengambil masa yang lama berbanding tebus rugi dalam bentuk baik pulih atau penggantian barang. Namun begitu, hal ini bergantung pada kesesuaian barang dan perkhidmatan yang diterima. Contohnya dalam kes yang diperhatikan, Pihak Yang 
Menuntut memilih untuk tebus rugi dalam bentuk wang ringgit walaupun Pihak Penentang boleh menggantikan barang elektrik yang rosak tetapi masih dalam tempoh jaminan.

Walaupun jumlah tuntutan yang boleh difailkan di TTPM tidak melebihi RM25 000, namun perlu ditambah baik kepada jumlah yang lebih besar. Jumlah tersebut dilihat tidak mampu memenuhi keperluan pengguna pada masa kini berikutan kuasa membeli pengguna yang semakin tinggi. Selain itu, wujud sejumlah pengguna yang memfailkan tuntutan walaupun barang atau perkhidmatan yang dibeli melebihi jumlah tersebut.

Seterusnya, pihak-pihak yang terlibat juga akan dibantu oleh pegawai yang terlibat sebelum prosiding kes berjalan di mahkamah tribunal, terutamanya dalam urusan pendaftaran dan pemfailan kes agar mengikut peraturan yang telah ditetapkan. Prosiding kes juga akan berjalan walaupun Pihak Penentang tidak hadir. Namun begitu, setelah segala prosedur telah dibuat mengikut peraturan dan award tetap perlu diserahkan kepada Pihak Penentang walaupun tidak hadir pada hari keputusan dibuat. Tuntutan kes dapat diselesaikan dalam tempoh masa yang cepat, misalnya dalam masa satu hari jika segala prosedur telah dibuat dengan baik oleh pihak terlibat dan presiden berpuas hati dengan segala keterangan yang dikemukakan. Jika terdapat masalah berkaitan dengan borang yang terlibat atau keterangan tidak mampu mencapai tahap kewajaran untuk presiden membuat keputusan, maka pendengaran kes akan ditangguhkan ke suatu masa yang munasabah dan bergantung pada keupayaan pihak-pihak untuk mengemukakan bukti atau keterangan yang diminta oleh presiden. Misalnya, dalam kes yang diperhatikan, presiden boleh menangguhkan pendengaran kes supaya dibawa ke sebelah petang, berikutan Pihak Yang Menuntut menyatakan mendapatkan dokumen yang diperlukan dalam masa yang singkat. Jika sebaliknya, maka kes ini akan ditangguhkan pada masa yang lain bagi memberikan peluang kepada pihak-pihak mengemukakan perkara yang diarahkan oleh presiden sebelum award dikeluarkan.

Alasan penghakiman yang disediakan oleh presiden tribunal pula penting untuk membantu pihak-pihak yang ingin membuat semakan kehakiman ke mahkamah tinggi sivil bagi mengenal pasti asas kehakiman yang dibuat sekiranya terdapat sebarang keraguan atau pihak yang tidak berpuas hati terhadap keputusan award yang dikeluarkan. Namun begitu, semakan kehakiman ini dilihat memberikan peluang kepada Pihak Penentang untuk sengaja melengah-lengahkan pelaksanaan award yang dikeluarkan kepada Pihak Yang Menuntut dan menimbulkan ketidakadilan kepada Pihak Yang Menuntut kerana tiada ruang yang diberikan untuk 
rayuan dibuat setelah award dikeluarkan oleh presiden. Oleh itu, isu ini perlu diperhalusi lagi oleh pihak berkaitan supaya memberikan keadilan sewajarnya kepada pihak-pihak yang terlibat.

Meskipun tiada standard khusus yang perlu diikuti oleh presiden ketika membuat sesuatu keputusan award, namun hal ini tidak menghalang presiden untuk berlaku adil dan berpegang kepada prinsip keadilan berpandukan keterangan dan bukti yang dikemukakan oleh pihak-pihak terlibat. Walaupun tiada garis panduan khusus kepada presiden dalam membuat sesuatu keputusan award, namun hal ini tidak memberikan kesan kepada tempoh presiden mengeluarkan sesuatu keputusan award dan kes boleh diselesaikan dalam masa satu hari sahaja bertepatan dengan peraturan dan peruntukan undang-undang dengan memberikan peluang dan ruang secukupnya kepada pihak-pihak untuk mengemukakan keterangan dan bukti untuk membuktikan atau menafikan tuntutan.

Selain itu, kaedah penyelesaian secara baik oleh pihak-pihak juga dilihat merupakan usaha yang baik dan disyorkan oleh mahkamah tribunal seperti yang telah diperuntukkan oleh undang-undang itu serta dianjurkan oleh presiden dalam setiap kes yang dihadiri oleh kedua-dua pihak bertikai.

Sedikit sebanyak hal ini dapat membantu pihak-pihak mencapai persetujuan yang dapat memuaskan hati masing-masing, mencapai suasana yang harmoni bagi mencari penyelesaian terbaik serta mengurangkan konflik yang mungkin wujud serta mengelakkan timbulnya permusuhan. Selain itu, perkara ini dapat menjimatkan masa dan kos pihak-pihak misalnya kos perjalanan sepanjang prosiding berjalan. Pendengaran kes tidak perlu didengar dalam tempoh masa yang panjang dan persetujuan tersebut dapat dijadikan perintah seterusnya mempercepatkan tebus rugi kepada pihak yang teraniaya.

\section{KESIMPULAN}

Perundangan yang berkaitan dengan kepenggunaan berkait rapat dengan keadilan dan masyarakat. Undang-undang digunakan sebagai alternatif utama untuk mencapai keadilan. Sistem mahkamah atau ciri-ciri litigasi mahkamah yang mempengaruhi tanggapan pengguna, seperti kos kewangan yang tinggi apabila menggunakan khidmat peguam yang mengendalikan kes tuntutan, kos masa, kelewatan proses di mahkamah, kegagalan mahkamah menangani masalah kes tertangguh yang sedia ada telah menimbulkan perasaan tawar hati dalam kalangan pengguna untuk memulakan tuntutan mereka di mahkamah akhirnya memberikan 
kesedaran kepada pengguna bahawa hakikatnya nilai tuntutannya sama sekali tidak berpadanan dengan kos prosiding yang terpaksa ditanggung oleh mereka. Oleh itu, mekanisme lain diperlukan sebagai medium untuk mendapatkan keadilan di luar sistem kehakiman. Walaupun prosesnya masih mirip kepada sistem mahkamah dari segi pemfailan kes, TTPM telah memudahkan pengguna untuk mendapatkan keadilan.

Secara umumnya, proses pelaksanaan dan penyelesaian kes di TTPM walaupun mirip sistem mahkamah sivil dari segi pemfailan kes, TTPM dilihat lebih mesra pengguna kerana tidak serumit proses di mahkamah sivil. Proses di TTPM dilihat agak mudah dan cepat, iaitu bermula daripada pemfailan kes sehinggalah award dikeluarkan. Tambahan pula, bayaran bagi pemfailan setiap kes atau borang sangat murah iaitu RM5 sahaja dan masih dalam kemampuan para pengguna di Malaysia. Berdasarkan pemerhatian yang dilakukan, keseluruhannya, TTPM telah dilihat mencapai peranan dan fungsinya dalam memberikan jaminan perlindungan kepada pengguna di Malaysia. Namun begitu, terdapat beberapa isu yang perlu dinilai dan dikaji dari masa ke masa bagi menambah baik kecekapan pengurusan di TTPM serta meningkatkan lagi tahap kepercayaan masyarakat terhadap fungsi dan peranan TTPM . Selain itu, pengguna sendiri memainkan peranan yang sangat penting. Mereka perlu mengambil langkah yang sewajarnya berhadapan dengan situasi ketidakadilan di pasaran, sekali gus memastikan hak mereka terpelihara, digunakan dan diadili sebaiknya. Prosedur tuntutan juga telah dimudahkan, mekanisme prosedur tuntutan di TTPM yang dilihat mesra pengguna sedikit sebanyak telah berjaya membantu pengguna. Selain itu, TPPM bertindak sebagai forum untuk menjaga kepentingan mereka dan menjadi pilihan utama pengguna untuk meluahkan ketidakpuasan hati melalui medium yang betul bagi membendung perlakuan tidak beretika dalam kalangan peniaga.

\section{RUJUKAN}

Afida Mastura Muhammad Arif. (2001). Sejarah pergerakan pengguna. Jurnal Pengguna Malaysia, 2.

Azimon Abdul Aziz. (2015). Mekanisme penyelesaian pertikaian. Sakina Shaik Ahmad Yusoff, Rahmah Ismail \& Shamsuddin Suhor (Eds.), Pengguna dan Undang-undang. Bangi: Penerbit Universiti Kebangsaan Malaysia, 2015),

Azimon Abdul Aziz, Sakina Shaik Ahmad Yusoff, Rahmah Ismail, Shamsudin Suhor, Kartini Aboo Khalid \& Muhammad Rizal Razman. (2011). Permasalahan dalam mekanisme penyelesaian pertikaian pengguna: Impak 
ke atas pengguna dalam mendapatkan keadilan. Prosiding Perkem VI, Jilid

1. Bangi: Universiti Kebangsaan Malaysia.

Akta Perlindungan Pengguna 1999 (Akta 599).

Aturan 53 Kaedah-kaedah Mahkamah 2012.

Joon, Christie Ding Yean dan Sakina Shaik Ahmad Yusoff. (2016). Perkembangan perlindungan pengguna: Cabaran dan hala tuju institusi pelindung pengguna di Malaysia. Jurnal Undang-undang dan Masyarakat, 20.

Kementerian Perdagangan dalam Negeri dan Hal Ehwal Pengguna, laman sesawang rasmi KPDNHEP, dicapai 3 Mac 2018, https:/www.kpdnhep.gov. $\mathrm{my} / \mathrm{kpdnhep} /$ tribunal-tuntutan-pengguna-malaysia-ttpm/.

Mohamad Fazli Sabri. (Jun 2014). The development of Consumer Protection Policies in Malaysia. International Journal of Business and Social Research (IJBSR) 4(6).

Mohamad Shariff Abu Samah. (2011). Undang-undang dan perlindungan pengguna. Kuala Lumpur: International Law Book Service.

Mohd Hamdan Adnan. (2005). Perjuangan perundangan pengguna. Petaling Jaya: IBS Buku Sdn. Bhd.

Naemah Amin dan Elistina Abu Bakar. (2010). "ADR for Consumers: An Appraisal of the Tribunal for Consumer Claims Malaysia," dalam Mediation in Malaysia: The Law and Practice (Singapore Pte. Ltd: Lexis: Nexis, 2010).

Pejabat Ketua Pendaftar Mahkamah Persekutuan Malaysia, dicapai 29 November 2018, http://www.kehakiman.gov.my/ms/mahkamah-majistret.

Peraturan-peraturan Perlindungan Pengguna TTPM 1999.

Sakina Shaik Ahmad Yusuf \& Rahmah Ismail. (2011). Perlindungan pengguna di bawah Undang-undang Pembekalan dan Perkhidmatan," Jurnal Undangundang dan Masyarakat, 12.

Diperoleh (received): 03 Mei 2020

Diterima (accepted): 02 September 2020 